\title{
Master Degree's Obsession in Indonesia: The Difference of Interpersonal Communication between $X$ Generation and $Y$ Generation
}

\author{
Rizky Fauziah
}

\author{
North Sumatera University, Medan, Indonesia \\ rizkyfauziahlbs@gmail.com
}

\begin{abstract}
Nowadays, having master degree in Indonesia is a new kind of lifestyle. For some reasons are to earn it such as to enrich their knowledge, in order to bureaucracy interest, or just for pride/social status. These reasons cause many people from all age level go to college as soon as possible including X and Y Generation. X Generation (1965-1980) main characteristic is sceptical who assumed working as a problem; and Y Generation (1981-1995) main characteristic is realistic who focused on achieve the outstanding working result with good ethics in it. The difference between X and Y Generation become a problem while being student in one class. There is a study orientation gap from both generation which affect the interpersonal communication. Later, this gap affect the study quality because of the unsolve of interpersonal communication.
\end{abstract}

Keywords: generations difference, interpersonal communication, master degree, X Generation, Y Generation

\section{INTRODUCTION}

Different generational styles in regards to communication behaviors can present organizational relationship challenges; some behaviors are expected across all generations such as reliability, respect for others, and adherence to confidentiality. Other behaviors have different expectations depending on the generation, such as: feedback, technology, work ethic and flexibility (Generations, 2011). These different generational styles can lead to defensive communication climates if not carefully managed (Phillips, 2011).

Moving chronogically, the first generation introduced will be the Traditional Generation also known as the Silent Generation born between 1922 and 1945. The next is the Baby Boomers which include those who were born between 1956 through 1964. Generation $\mathrm{X}$ includes all individuals born between the years of 1965 and 1980. They see themselves as independent people who are able to market themselves successfully. They are more independent than both the silent generation and the baby boomers. Generation Y who are also known as the Millenials including people who were born between the years 1981 to 1995. This generation's beliefs and values are almost the polar opposite of the silent generation. They highly value their free time and do not define themselves through their job. Instead, they value the impact they are able to make on the community through their active involvement in things that matter to them (Kelly et al, 2016).

According to Fox (2011), Generation Y thinks Generation $X$ managers are "jaded, bitter, abrasive, not interested in them, hoard their knowledge and don't delegate" (p.24). Generation Xers see themselves as self-reliant, used to doing everything on their own and do not like "hand-holding". They often feel that because they were not mentored, they do not have to mentor the next generation and expect them to just do their job.

Generation Y works well in groups and expect structure in the workplace, acknowledge and respect positions and titles, and want a relationship with their boss; this doesn't always work well with Generations X's independent and hands-off styles (Simon, 2010). Generation $Y$ has also had a very privileged upbringing in terms of the economy, wars, politics, home life, and access to technology. This has made them less likely to put up with poor treatment from others and sets the stage for an "us vs. them" mentality and generational conflicts (McCready, 2010).

Generation $Y$ tends to favor selective amounts of effort and is able to process information and switch tasks much faster than previous generations; there is even evidence that the brain is changing in response to digital stimuli (Tapscott, 2009). These hard-wired brain changes may be the reason behind 
different preferences of communication styles (Phillips, 2011).

Today both X-Gen and Y-Gen come together to college specially in master degree in Indonesia. Each of these generational groups of students brings individual learning styles (Williams et al, 2014). By the data from Kementerian Pendidikan dan Kebudayaan (Kemdikbud) of 2014 the master degree alumnae is increasing from year to year. The increase is about $18,67 \%$ per year from 11.109 to 36.816. It means master degree obsession is happening in Indonesia.

The numbers shows that there is a big possibility for X-Gen and Y-Gen to be in the same class while they are taking master program. When both generation studying at the same class, they hard to talk to each other because the different point of view. XGeneration see themselves as self-reliant who do everything as what they want, Y-Generation see themselves as curiosity person who interested in learning something new.

This generational difference cause the bad interpersonal communication because each of them has different background. When both of this generation studying in the same class they hard to talk to each other caused by different perceptions in following the master program. Perceptions is the organization, identification, and interpretation of sensory information in order to represent and understand the environment (Schacter \& Daniel, 2011). All perception involves signals in the nervous system, which in turn result from physical or chemical simulation of the sense organs (Goldstein, 2009).

In psychology, perception is being broken down into five steps or processes (Devito, 2009):

\section{a. Stimulation}

Stimulation is the step, which the senses are being stimulated when information are perceived. Various stimuli come into effect base on individual's sight, smell, taste, touch and hearing (Devito, 2009)

\section{b. Organization}

In the step of Organization information is picked up by the senses and being organized. There are three ways in which perception is being organized. Firstly, by rules, secondly through schemata, and thirdly scripts (Devito, 2009).

c. Interpretation-Evaluation

Interpretation-Evaluation: a linked term due to the association between the two processes. It can be greatly affected by the experience, needs, wants, value, expectation, physical and emotional state, gender, and beliefs of how things should be, including the step organization (Beebe, Beebe \& Redmond, 2002 \& Devito, 2007).

d. Memory

Memory stores information after undergoing steps of stimulation, organization and interpretation-evaluation. Nevertheless, information is not constantly stored, due to the accumulated impressions of past correspondence and associate with things. Hence, information or details may be lost or distorted easily when they are dissimilar or a mismatch with what is already in our memory. On the other hand, information that is consistent with our schema will strengthen our ability to store them and is more resistant to changes (Aronson, Wilson, \& Akert, 2002).

e. Recall

Recall: Memory is not reproductive, it is reconstructive. Based on your schema and scripts, you take the tagged elements to recreate what happened previously (DeVito, 2007).

From this five stages of perceptions, this research is purposed to discover the perception difference among the generation gap. By using this, the research is about to find out what is the perception difference between $\mathrm{X}$-Gen and Y-Gen in following master program for higher education. This research is to find out how both generation communicate during the class process in master program. The discovering is useful to solve the lack of interpersonal communication of both generation.

\section{RESEARCH METHOD}

This research is using qualitative method to describe the perception of the master degree's student and alumnae in Indonesia about their purpose following this education program. For more, the perception is measured by the five stages; what is their stimulation following the master program, their point of 
view about the importance of master degree program, what is their interpretation of master degree based on the accomplished class, what they remember about the program, and how they conclude overall of the program.

The research data based on depth interview to 4 people who represent the master degree student and master degree alumnae. For master degree student will be represented by 1 student from X-Gen and 1 student from Y-Gen which still following the master program. For master degree alumnae will be represented by 1 alumnae from X-Gen and 1 alumnae from Y-Gen.

Table 1. Informant List

\begin{tabular}{|c|c|c|c|}
\hline Status & Name & Generation & University \\
\hline \multirow[t]{2}{*}{$\begin{array}{l}\text { 1. Master Degree } \\
\text { Student }\end{array}$} & a) NM (Female) & $\begin{array}{l}\text { born on } 1993 \text { (Y- } \\
\text { Gen) }\end{array}$ & Telkom University \\
\hline & b) S (Male) & $\begin{array}{l}\text { Born on } 1970 \text { (X- } \\
\text { Gen) }\end{array}$ & UPI “YPTK” Padang \\
\hline \multirow[t]{2}{*}{$\begin{array}{l}\text { 2. Master Degree } \\
\text { Alumnae }\end{array}$} & a) RJ (Female) & $\begin{array}{l}\text { Born on } 1990 \text { (Y- } \\
\text { Gen) }\end{array}$ & UPI “YPTK” Padang \\
\hline & b) APL (Master) & $\begin{array}{l}\text { Born on } 1963 \text { (X- } \\
\text { Gen) }\end{array}$ & $\begin{array}{l}\text { Universitas Medan } \\
\text { Area }\end{array}$ \\
\hline
\end{tabular}

The informant chosen by their experience as the master student; how they follow the class, their interaction with the classmate, their way doing teamwork; how they solve miscommunication; or master alumnae; how they finished the classes, their opinion about the class process, how they fight with all of the obstacles during semester, how they see their master degree program impact to their life after graduated.

\section{RESULTS}

The result of this research is based on depth interview with 4 informants; 2 person from the master student and 2 person from the master alumnae. From the master student, the first informant is NM, the student of Management Master Program at Telkom University Bandung. She started her master program on August 2015 until now. She stayed at Bandung during her studying process. The second informant is $\mathrm{S}$, the student of Computer Master Program at Universitas Putra Indonesia "YPTK" Padang. He started his master program on February 2016. He lived in Pekanbaru, come to Padang twice a month to attend the class.
From the alumnae, the first informant is RJ. She graduated from Computer Science Master Program at Universitas Putra Indonesia Padang "YPTK" Padang on October 2016. She worked at a health science university in Bengkulu. The second informant is APL. He graduated from Agriculture Business Master Program at Universitas Medan Area on May 2010. He is the executive management of a computer university in Kisaran.

The five stages is a tool to measure the perception of each representative from each generation. By using this stage we can discover the stimulation, what are their reason following the master program. It might be for improving knowledge, to improve their career at the office, or maybe just to upgrade their social status. Second stage, organization, is useful to define what is the master student and master alumnae perception about the master program itself. It might be a good learning process, or unqualified, and maybe the class just for fulfill the education system.

Third stage, interpretation-evaluation is useful for understanding what is the master program mean for the student and alumnae. Do they really studying or just doing the classcheck attendance? Fourth stage, memory, is 
used to know how they define the master program. What do they remember about it, the class, the lecturer, or maybe just the day-off moment? Fifth stage, recall, how do they explain their master program and what is the impact for their life.

\begin{tabular}{|c|c|c|c|c|c|c|}
\hline \multirow[t]{2}{*}{ Status } & \multirow[t]{2}{*}{ Name } & \multicolumn{5}{|c|}{ Perception Stages } \\
\hline & & $\begin{array}{l}\text { Stimulatio } \\
\text { n }\end{array}$ & Organization & $\begin{array}{l}\text { Interpretation } \\
\text { / Evaluation }\end{array}$ & Memory & Recall \\
\hline 1. Student & $\begin{array}{l}\text { a) NM } \\
\text { (Y } \\
\text { Gen) } \\
\text { b) S } \\
\text { (X } \\
\text { Gen) }\end{array}$ & $\begin{array}{l}\text { Improving } \\
\text { Knowledge } \\
\text { Bureaucrac } \\
\text { y Interest }\end{array}$ & $\begin{array}{l}\text { Handled by } \\
\text { professional } \\
\text { lecturer } \\
\text { Right place to } \\
\text { help } \\
\text { following } \\
\text { bureaucracy } \\
\text { interest }\end{array}$ & $\begin{array}{l}\text { Student } \\
\text { centered } \\
\text { learning } \\
\text { process } \\
\\
\text { Lecturer } \\
\text { centered } \\
\text { learning } \\
\text { process }\end{array}$ & $\begin{array}{l}\text { Applicable } \\
\text { Knowledg } \\
\text { e }\end{array}$ & $\begin{array}{l}\text { Fulfill } \\
\text { the } \\
\text { knowle } \\
\text { dge } \\
\text { Fulfill } \\
\text { the } \\
\text { bureauc } \\
\text { racy } \\
\text { interest }\end{array}$ \\
\hline 2. Alumnae & $\begin{array}{l}\text { a) RJ } \\
\text { (Y } \\
\text { Gen) } \\
\text { b) APL } \\
\text { (X } \\
\text { Gen) }\end{array}$ & $\begin{array}{l}\text { Improving } \\
\text { Career } \\
\\
\text { Social } \\
\text { Status }\end{array}$ & $\begin{array}{l}\text { Technology } \\
\text { based class } \\
\text { Various } \\
\text { student with } \\
\text { various } \\
\text { background }\end{array}$ & $\begin{array}{l}\text { Text book } \\
\text { based learning } \\
\text { process }\end{array}$ & $\begin{array}{l}\text { Unfair } \\
\text { Teamwor } \\
\text { k Project } \\
\\
\text { Monoton } \\
\text { learning } \\
\text { process }\end{array}$ & $\begin{array}{l}\text { Spreadi } \\
\text { ng } \\
\text { network } \\
\text { link } \\
\text { Upgradi } \\
\text { ng } \\
\text { social } \\
\text { status }\end{array}$ \\
\hline
\end{tabular}

Table 2. Perception Stages

From the table above we can see how $\mathrm{X}$ Generation and $Y$ Generation different in defining and following the master program. Here are the detail explanation of each perception stages between the $\mathrm{X}$ Generation and Y Generation.

\section{$X$-Gen vs. Y Gen: Stimulation in Following the Master Program}

They were asked about what is their main reason in following the master program. The result is X Gen mostly said that the program is for their own interest such as upgrading social status or in order to bureaucracy interest in the workplace. This reason might be caused by their background as the main worker at their workplace or parents in their family. They define the master program based on their willing for their life goodness.

The Y Gen defines the master program as a developing knowledge education level. They see the master program will be the right moment to improve the knowledge so it makes a good impact for their career and the future.

This different stimulation in perception stages leads the communication to the misperception because they have different point of view. X-Gen defines it by their interest, to fulfill their need. Y-Gen defines it for better future and better understanding in learning.

\section{$X$-Gen vs. Y Gen: Organization in Defining the Master Program}

They were asked about what is their opinion about the master program itself. The result is $\mathrm{X}$ Gen mostly said that master program is the right place to fulfill the bureaucracy interest and to find various people from various backgrounds. They want to get more advantages from master program to their life quality. The Y Gen said that master program is the right place to meet professional lecturers even experts and will be the technology-based class. Y Gen want to fulfill 
their curiosity about something new and learn about the knowledge update.

This different motivation shows that XGen wants to put their interest become the priority. They not really interested in discovering new knowledge. The Y-Gen defines the master program to upgrade their knowledge from the professional lecturers so they get better understanding. They want to learn about technology too in learning process so they have unlimited access to study every time and everywhere.

\section{$X$-Gen vs. Y Gen: Interpretation/ Evaluation of the Meaning of Master Program}

They were asked about what is the meaning of master program for them. In other words, the question is to know how they think the class going on during the master program. For X-Gen, the class must be lecturer-based and text book learning process. It's difficult to understand the slide from the lecturer in class. They prefer the long explanation from the lecturer and feel comfort with theory book.

The Y-Gen think that the master program is a student centered process equipped with e-learning. Lecturer as a facilitator during the class is helping to give a little explanation and give the student free access to develop the knowledge in every way. The technology is really help the study process because it opens so many sources to study and learn a lot about new knowledge.

The different in interpreting the master program affect the study orientation between both generations. X-Gen wants to make the study process as simple as their old school learning style. Y-Gen wants the e-learning process so they can study as free as they want.

\section{X-Gen vs. Y Gen: Memory of The Class Process in Master Program}

They were asked about how does the class going on during the master program. The $\mathrm{X}-\mathrm{Gen}$ answered that the learning process in the class in static and theory overloaded. They said that the class in too boring and did not engage them in that. The Y-Gen answered that the class is teaching the student about applicable knowledge. But they also complained about the teamwork project that include in class process. They said that this project is unfair because only the junior want to do that. The senior (by age) did not involve in making the task but forcing their name to be put in it.

This condition caused the conflict between both generations because each of them feels disappointed eventually. None of them try to make the win-win solution, because the X-Gen feels they do not involved in, and Y-Gen feels the seniors (X-Gen) don't want to participate in making the project.

\section{X-Gen vs. Y-Gen: Recall the Impact of Master Program}

They were asked about what is the impact of master program for their life. The XGen said that master program is useful to fulfill the bureaucracy interest and upgrading social status. They feel good to know the new knowledge but they prefer the other impact who relate directly to their life. Master program allow them to meet students with various backgrounds.

The Y-Gen said that master program is very useful to upgrade their knowledge and spreading their network link. They are so thankful to meet a lot of professional lecturer during the class and meet so many people who shared them new information or knowledge.

\section{CONCLUSIONS}

From the explanation about the research about the difference of interpersonal communication X-Gen and Y-Gen on following master program, we can conclude that:

1. The different perceptions come from the different perception stages between X-Gen and Y-Gen since the first time they started the master program. The different caused the different motivation and the study orientation eventually.

2. The different perceptions affect the learning style between both generations that make a communication gap. Interpersonal communication can not working because both generations failed to do sympathy to understanding each other.

3. Every generation come from different background and every difference is normal. Since the rapid changes by the technology, XGen and Y-Gen shaped in the different way. 
4. Higher education supposed to be the right place to improve the knowledge. Education system must be the main standard to generalize all the differences between $\mathrm{X}$ Gen and Y-Gen.

\section{REFERENCES}

De Vito, Joseph H. (2002). The Interpersonal Communication Book, Pearson, United States.

Kelly, et al. (2016). "Generation Gaps: Changes in the Workplace due to Differing Generational Values", Journal of Advances in Management, Vol. 9 No. 5.

Kemdikbud. (2014). "Perkembangan Lulusan Menurut Program dan Jenis Lembaga PT tahun 1999/2000-2013/2014", available

www.publikasi.data.kemdikbud.go.id (accessed 9 November 2016).

Mohammadi and Banirostam. (2015). " A Perceptual Meta-Model based on the Ontology of Mental Models", The International Journal of Humanities and Social Studies, Vol. 3 No. 11.

Phillips, Stacy. (2011). "X and Y: The Impact of the Gap", thesis, Gonzaga University School of Professional Studies.

Williams, et al. (2014). "Generational Perspective of Higher Education Online Student Learning Styles", Journal of Education and Learning, Vol. 3 No. 2. 